\title{
Appraisal of Competency Improvement Needs of English Language Educators in Teaching Reading and Writing Skills with Multimedia Aids
}

\author{
CHIKELU Jennifer Ujunwa \\ Department of English, Institute of Ecumenical Education, Enugu \\ MOGBOH Vero, Ph.D \\ Department of Educational Foundation, Godfrey Okoye University, Enugu \\ OKOYE Alexander Chukwuemeka \\ Department Science and Vocational Education, Godfrey Okoye University, Enugu
}

\begin{abstract}
The main purpose of this study was to ascertain the competency improvement need of English language teachers for adoption of multimedia instructional aids in teaching reading and writing skills in senior secondary schools in Enugu education zone. Descriptive survey research design was adopted in order to determine the specific skill set for teaching two language skills of reading and writing. Disproportionate sampling technique was used to select 100 teachers from 5 schools from each of the 3 LGAs in the study area from the population of 31 senior secondary schools and 183 English teachers. A researcher developed instrument titled Competency Improvement Questionnaire (CIQ) was used to draw out the gap between a predetermined proficiency level for effective instruction with the use of multimedia instructional aids and English language teachers' skill set in the use of multimedia instructional aids. Data were arranged and interpreted using mean ratings and decisions were taken using the limit of real numbers according to research questions. Findings show that English language teacher' proficiency level in the use of multimedia aids to teaching reading and writing skills are demanding. Hence, the major educational implication of the findings of the study is that there is still need for improvement in the programme delivery to meet the demands of quality teaching of language skills with multimedia aids in secondary education. The main recommendation is that teacher preparation institutions should incorporate Hanson courses and programme in the relevant areas of the use of modern instructional aids
\end{abstract}

Keywords: Competency, English Language Readinging Skills, Writing Skills and Multimedia Aids

DOI: $10.7176 /$ RHSS/9-18-05

Publication date:September $30^{\text {th }} 2019$

\section{Introduction}

Proficiency in these skills is an essential pre-requisite for further learning, which is also congruent to English as the official language of the nation. As official language of communication in Nigeria, English language functions as a vehicle of interaction and an instrument of communication. According to Hamisu, Sani, Umma and Maryam (2018), due to its role in social, political, economic and environmental development, the importance of English language cannot be overemphasized. The key function of language use is for effective interpersonal communication and its primary goal for learners is to develop communicative competence (Ying, 2010). Hence, Tan (2016) opined that current linguistic and psycholinguistic theories suggest that efforts to teach language to human learners should actively engage them in the learning process.

Such active engagement consists of providing opportunities to explore and implore about language rather than simply requiring learners to memorize bits of language. Nonetheless, as observed by Akhtar (2017), to teach English and develop English language skills, various approaches and methods are in use but most of them are traditional, less interesting, ineffective as well as less motivating. So, it is necessary to use modern approaches and instructional aids to develop better understanding and acquisition of basic skills of Listening, Speaking, Reading, and Writing (LSRW). Realizing the significance of communicative competence in English language, most of the developed countries of the world have shifted from traditional to modern pedagogical practices by incorporating modern instructional aids (Yasmin, 2018). Contemporary educators thus encourage teachers to rethink their approach using well-planned and well-designed instructional materials (Tan, 2016). Instructional materials are aids to learning. Modern instructional materials are multimedia based aids. Multimedia technology refers to computer-based interactive applications that use both the hardware and software, allowing students to share their ideas and information. It is a combination of text, graphics, animation, video and sound (Pun, 2013).

However, the poor performance of Nigerian students in external English examinations has continued to be a source of worry to parents, educational stakeholders and the government, Akeredolu-Ale (2007) and Muhammad, Aliyu and Hassan (2018). This delinquency has impeded the transition to higher education of many Nigerian 
students. For instance, there have been incidents of mass failure recorded at the primary and junior secondary examinations conducted in the country (Asikhia, 2010). Again, at the senior secondary and tertiary levels, reports also abound on the continual failure of students in English (Adekola, 2012) and Ayodele (1998), and these have been attributed to their faulty foundation (West African Examination Council (WAEC) (2017).

Nevertheless, observation of the researcher suggest that the adoption and changes envisioned by modern instructional aids require teachers both to develop requisite skills and competencies for a deeper understanding of English language and to construct new understandings of the teaching and learning. This has significant implications for schools and the current discourse about the role of teacher quality and effectiveness in improving educational outcomes. What is rarely discussed in these debates, however, is what teacher competence is needed to bring about the needed accountability on the part of the teacher. Teacher competence refers to teacher's well use of knowledge, resources skills and attitude in classroom for effective instructional delivery. Competencies are the positive combinations of knowledge, ability and willingness in the ability of the individual to cope successfully and responsibly with changing situation (Okwelle and Allagoa, 2014).

They are tools of teaching and only teachers who possess the prerequisite skills, knowledge and attitudes needed to function effectively with modern instructional media in the classroom situation are competent to teach in the situation. For this reason, teacher competence in instructional delivery is a vital input in realizing the objectives of English language education. Because English language in the Nigerian educational system is central, and the political and social circumstances make the use of English language imperative not only as a foreign language but an official language, it is indispensable that the language is properly taught so that pupils can have effective mastery of the subject (Oribabor, 2014). These places a new demand on educational researchers in making conscious efforts to boost English language teachers' ability to perform the task and roles required in a modern English language classroom and lab to the expected standards. The above obligation has made this present study apt.

\section{Statement of the Problem}

Multimedia aids have the potential not only to improve communicative competence in language skills, but also to empower people, strengthen governance and galvanize the effort to achieve the goal of secondary education. Nonetheless, the complexity of modern instructional aids could offer a formidable challenge to the English language teacher, who may be almost overwhelmed by the mass of details and skill set required of him/her to be efficient. The problem of this study therefore is that there is no empirical study on the competency improvement needs of English language teacher in Enugu education zone in the use of multimedia aids that could be used to design an improvement programme in teaching reading and writing skills.

\section{RESEARCH METHODS}

This study adopted descriptive survey research design. Descriptive Survey research design aims to obtain information from a representative sample of the population which the investigator presents the findings as being representative of the population as a whole. According to Nworgu (2015), survey research is the systematic collection of data from a group as a representative sample of the population. This research design is considered appropriate by the researcher because it will allow the researcher to collect data from a sample and make inference about the population.

The population of this study consists of all the 183 English teachers in the 31 senior secondary schools in Enugu education zone. This consists of the 90 English teachers in 9 public schools in Enugu North, 51 English teachers in the 10 public schools in Enugu East and the 42 English teachers in the 12 public senior secondary schools. The sample for this study is 100 English Language teachers. Disproportionate sampling procedure was first used to select 5 schools from each of the 3 LGAs in the study area. All the teachers in the selected schools were subsequently used because the sub population is manageable.

A researcher developed instrument titled Competency Improvement Questionnaire (CIQ) was used for data collection. CIQ was designed to draw out the gap between a predetermined proficiency level for effective instruction with the use of multimedia instructional aids and English language teachers' skill in the use of multimedia instructional. CIQ has sections A and B. Section A is demographic while section B is in two clusters, one for each research question. Cluster one has 12 items on skills needed for teaching reading with multimedia, cluster two has 11 items on writing.

The data collected were analyzed using descriptive statistical tools with SPSS version 20.0. However, CIQ was first given to three language educators in tertiary education to determine an acceptable minimum competency benchmark needed for English language teachers to be effective in the use of multimedia instructional aids. A benchmark of 3.0 was approximated from the average ratings of the three language educators. To answer the research questions that guided this study thereafter, data obtained were interpreted using the limit of real numbers. Hence, mean scores and standard deviation were used for the questionnaire items. In determining the competency improvement needs of the studied English Language teachers for each item, the 
mean scores obtained were deducted from the predetermined minimum proficiency level set by the language educators for effective instruction with the use of multimedia instructional aids in teaching the four language skill.

\section{RESULTS}

Research Question One: What are the multimedia competency improvement needs of English language teachers in teaching reading skills?

Table 1: Competency needs of English language teachers for effecting teaching of reading skills with the aid of multimedia

\begin{tabular}{|c|c|c|c|c|}
\hline $\mathbf{S} / \mathbf{N}$ & Items & $\mathbf{X}$ & $\begin{array}{l}\mathbf{P}- \\
\mathbf{X}\end{array}$ & SD \\
\hline 1 & I download Blog materials for my students to read & 2.8 & 0.2 & .98 \\
\hline 2 & $\begin{array}{l}\text { While using digital libraries, I can search library database for appropriate } \\
\text { pronunciation of words }\end{array}$ & 2.6 & 0.4 & .91 \\
\hline 3 & I can use blog facilities to stimulate my students for reading practice & 2.2 & 0.8 & .97 \\
\hline 4 & I use digital pronunciation dictionaries to aid my students reading drills & 2.1 & 0.9 & 1.01 \\
\hline 5 & $\begin{array}{l}\text { I can retrieve recorded audio materials while navigating the internet to incite my } \\
\text { students reading speed }\end{array}$ & 2.2 & 0.8 & 1.01 \\
\hline 6 & I can create electronic presentation on the projector for my students to read & 2.3 & 0.7 & 1.02 \\
\hline 7 & $\begin{array}{l}\text { I can transmit downloaded documentaries through power point connected to smart } \\
\text { screen for reading practice }\end{array}$ & 2.2 & 0.8 & .99 \\
\hline 8 & $\begin{array}{l}\text { I can navigate the web by use of link and URL addresses to download } \\
\text { comprehension passages for my students to read }\end{array}$ & 2.2 & 0.8 & 1.09 \\
\hline 9 & $\begin{array}{l}\text { I can use smart phone apps to locate desired informative passages for my students } \\
\text { to read }\end{array}$ & 2.3 & 0.7 & 1.09 \\
\hline 10 & I can use digital notebook to enhance the reading ability of my students & 2.2 & 0.8 & 1.08 \\
\hline 11 & I can upload e-mail well-articulated stories for my students to download and read & 2.1 & 0.9 & 1.02 \\
\hline 12 & $\begin{array}{l}\text { I can create group charts where my students can read my uploaded articles on social } \\
\text { media }\end{array}$ & 2.1 & 0.9 & 1.22 \\
\hline
\end{tabular}

Table 1 show that English language teachers have needs in all competencies for teaching reading skills with the aid of multimedia aids.

Research Question Two: What are the multimedia competency improvement needs of English language teachers in teaching writing skills?

Table 2: Competency needs of English language teachers for effecting teaching of writing skills with the aid of multimedia

\begin{tabular}{|c|c|c|c|c|}
\hline $\mathbf{S} / \mathbf{N}$ & Items & $\mathbf{X}$ & $\begin{array}{l}\mathbf{P}- \\
\mathbf{X}\end{array}$ & SD \\
\hline 1 & I can use email facilities to engage my students in writing & 2.6 & 0.4 & 1.02 \\
\hline 2 & I can use social media to introduce my students to article writing & 2.5 & 0.5 & 1.02 \\
\hline 3 & $\begin{array}{l}\text { I can stimulate my students to be effective writers my exposing them to mobile } \\
\text { applications }\end{array}$ & 2.2 & 0.8 & 1.08 \\
\hline 4 & $\begin{array}{l}\text { I can develop open questions on digital notebooks and students will fill in the gaps } \\
\text { online }\end{array}$ & 2.2 & 0.8 & 1.01 \\
\hline 5 & I can use virtual classroom to inspire my students to develop creative writ-ups & 2.0 & 1 & 1.01 \\
\hline 6 & I can use free and open source software to stimulate my students to write fictions & 2.3 & 0.7 & 1.07 \\
\hline 7 & $\begin{array}{l}\text { I can engage my students to take turns in imputing textual material displayed on the } \\
\text { computer }\end{array}$ & 2.1 & 0.9 & .98 \\
\hline 8 & I can use digital notebook to teach my students spelling & 2.1 & 0.9 & 1.01 \\
\hline 9 & I can use Ipad to engage my student for writing practice & 2.2 & 0.8 & 1.03 \\
\hline 10 & $\begin{array}{l}\text { I can create competition among the students by engaging them to be the first to } \\
\text { input words displayed on flashcards }\end{array}$ & 2.4 & 0.6 & 1.19 \\
\hline 11 & $\begin{array}{l}\text { I can develop instructional materials on the smart phones to aid my students in } \\
\text { writing }\end{array}$ & 2.1 & 0.9 & 1.04 \\
\hline
\end{tabular}

Table 2 show that English language teachers have needs in all competencies for teaching writing skills with the aid of multimedia aids.

\section{Discussion of the Findings of the Study}

Multimedia competency improvement needs of English language teachers in teaching reading skills

Reading is a learning skill that improves all parts of the English language - vocabulary, spelling, grammar, and 
writing. Hence, it's an important language skill that influences any other. Findings of this study however found out that in teaching speaking skills with multimedia aids, English language teachers have improvement needs to be able to download Blog materials for students to read; search library database for appropriate pronunciation of words while using digital libraries; stimulate students for reading practice with blog facilities; use digital pronunciation dictionaries to aid students reading drills and navigating the internet to incite my students reading speed. Other areas of improvement needs for teachers include the competency to create electronic presentation on the projector for students to read; ability to transmit downloaded documentaries through power point connected to smart screen for reading practice; navigating the web by use of link and URL addresses to download comprehension pass" ages for students to read; use of smart phone apps to locate desired informative passages for students to read; use digital notebook to enhance the reading ability of students; skills to upload email well-articulated stories for my students to download and read and; know-how to create group charts where my students can read my uploaded articles on social media. Second language learners always motivated to communicate through speaking and instructional aids have been found to boost performance in language learning. The findings of this study therefore is congruence to those of Young (2008) whose purpose of this study was to determine the effect that computer technology use in the classroom had on students' grades, motivation, attitude and attendance. For the most part, Young found out that the use of technology was motivating for the students, but it had no significant positive effect on their grades and/or attendance, including "at risk" students. In addition, the study found that the continued use of technology was low among the teachers in the sample due to low competency in the use of such modern aid. These results suggest that for technology to be effective and make changes in students' grades, motivation, attitude, and attendance, schools must be prepared for technology use in the classroom. This is also supports the findings of Adelodun and Asiru (2016) which examined the role played by instructional resources in enhancing speaking performance of students, especially that of high-achievers in English Language. The findings showed that instructional resource play a significant role in enhancing performance of high-achieving students in English Language and also revealed that there is a significant relationship between the use of audio, visual and audio visual materials and performance of high achieving students in the English Language.

\section{Multimedia competency improvement needs of English language teachers in teaching writing skills}

Writing provide language learner with physical evidence of achievements and can measure improvement. Writing skills helps to consolidate grasp of vocabulary and structure, and complements the other language skills. With respect to teaching writing skills with multimedia aids, it was found out that English language teachers need competency improvement to use email facilities to engage students in writing; social media to introduce students to article writing; virtual classroom to inspire my students to develop creative writ-ups; free and open source software to stimulate students to write fictions; digital notebook to teach my students spelling and; use of Ipad to engage student for writing practice. Other areas English teachers need improvement is in their ability to stimulate students to be effective writers by exposing them to mobile applications; develop open questions on digital notebooks and students will fill in the gaps online; engage students to take turns in imputing textual material displayed on the computer; creating competition among the students by engaging them to be the first to input words displayed on flashcards and skill set to develop instructional materials on the smart phones to aid my students in writing. These are similar to the findings of Naz (2016) whose objectives of study included to identify professional competencies of teachers in public Secondary Schools. Naz study revealed that there is a significant relationship between teachers' professional competence scores and students' achievement scores at public secondary schools. These professional competencies are also central to motivating their interest to learn, increase the students' regularity in classroom, and encourage learners' active participation in teaching and learning situation because the study of Nwangbo (2016) show that modern instructional materials influence the junior secondary school students by motivating their interest to learn, increase the students' regularity in classroom, and encourages learners' active participation in teaching and learning situation.

\section{Educational Implications of the Findings of the Study}

From the findings of the study, the English language teacher' proficiency level in the use of multimedia aids to teaching language skills are demanding. This is a worrisome situation because this implies that even if the Government provides and meets such infrastructural needs of implementing a programme of the use of multimedia instructional aids in schools, incompetence will constitute a challenge which would always deter effective utilization of the assistance multimedia knowledge can offer to the English teachers.

\section{Recommendations}

In the light of the findings and educational implications, the researchers make the following recommendations

1. Curriculum planners and developers should expose both the pre-service and in-service teachers to the techniques and skill set in the use of multimedia aids by imbedding such task in curriculum activities. 
2. Teacher preparation institutions should incorporate Hanson courses and programme in the relevant areas of the use of modern instructional aids

\section{References}

Adekola, B. (2012) Home and School Factors as Determinants of Students' Achievement in Secondary School English Comprehension in Four South Western States. Research Journal in Organizational Psychology \& Educational Studies, 1, 280-283

Akeredolu-Ale, B. (2007) Good English for What? Learners' Motivation as a Factor in Declining Learners' Performance in English Language Acquisition and Use of Nigerian Schools. Changing English: Studies in Culture and Education, 14, 231-245. http://dx.doi.org/10.1080/13586840701443065

Akhtar, S. (2017). Role of ICT in the Enhancement of English Language Skills among the Learners. Journal of Technology for English Language Teaching. Vol. 7(2)

Asikhia, O. (2010) Students and Teachers' Perception of the Causes of Poor Academic Performance in Ogun State Secondary Schools [Nigeria]: Implications for Counseling for National Development. European Journal for Social Sciences, 13, 229-242.

Ayodele, S. (1998) The Problem of a Language for Educating Nigerian Learners, Faculty of Education. 4th Annual Lecture, University of Ibadan, Ibadan. [Citation Time(s):2]

Hamisu A, Sani Y, Umma, I.and Maryam H. (2018). Teaching and Learning English Language in Nigerian Schools:Importance and Challenges. Teacher Education and Curriculum Studies. Vol. 3, No. 1, 2018, pp. 10-13. doi: 10.11648/j.tecs.20180301.13

Muhammad, H. A., Aliyu, S. I and Hassan, M. (2018). Teaching and Learning English Language in Nigerian Schools: Importance and Challenges. Teacher Education and Curriculum Studies. Vol. 3, No. 1, 2018, pp. 10-13. doi: 10.11648/j.tecs.20180301.13

Naz, K. (2016), Effects of teachers' professional competence on students' academic achievements at secondary school level in Muzaffarabad District, Munich, Master's Thesis, 2016 GRIN Verlag, https://www.grin.com/document/352095

Okwelle, P. C. and Allagoa, F. O. N. (2014). Enhancing Teachers' Competence in the Use of Instructional Materials in Electronics Education in Senior Secondary Schools in Nigeria Research on Humanities and Social Sciences. Vol.4, (28).

Oribabor, O. A (2014). An Evaluation of the Current English Language Curriculum in Nigerian Secondary Schools. Journal of Educational and Social Research. Vol. 4 No.6. pp: 295-300. Doi:10.5901/jesr.2014.v4n6p295

Pun, M. (2013). The Use Of Multimedia Technology In English Language Teaching: A Global Perspective. Crossing the Border: International Journal of Interdisciplinary Studies. Vol.1(1). Pp, 29-38.

Tan, J. G. (2016). English Instructional Materials: Imperative Learning Aid for the High School Bound Summer Program of the MSU-Science High School. International Journal of Learning, Teaching and Educational Research. Vol. 15(4), pp. 42-50.

West African Examinations Council (2017). Chief Examiners’ Report on English language..

Yasmin, F. (2018). Challenges to Computer Assisted Language Teaching at University Level. International Journal of Language and Literature December 2018, Vol. 6, No. 2, pp. 86-93

Ying, L. (2010). Communicative activities in ELT classrooms in China. Unpublished master dissertation, University of Wisconsin-Platteville.

Young, R. (2008). Using Technology Tools in the Public School Classroom. A Research Paper Submitted the Graduate School University of Wisconsin-Stout in Partial Fulfillment of the Requirements for the Master of Science Degree in Education. 